\title{
Inclusion of different levels of inulin on productive parameters and intestinal morphology in fattening guinea pigs (Cavia porcellus)
}

\author{
Fernando Carcelén Cáceres ${ }^{*}$ (D) Felipe San Martín Howard ${ }^{1}$ (D) Miguel Ara Gómez $^{1}$ (D) \\ Sandra Bezada Quintana ${ }^{1}$ (D) Ana Asencios Méndez ${ }^{1}$ (D) Luis Ruiz-García ${ }^{1}$ (D) \\ Rocío Sandoval-Monzón ${ }^{2}$ (D) Ronald Jiménez Aliaga ${ }^{3}$ (D) Rosa Perales Camacho ${ }^{2}$ (D) \\ Gilberto Santillán Altamirano ${ }^{2}$ (D) Jorge Guevara Vásquez ${ }^{4}$ (D)
}

\begin{abstract}
${ }^{1}$ Departamento de Producción Animal, Facultad de Medicina Veterinaria, Universidad Nacional Mayor de San Marcos, 15081, Lima, Perú. E-mail: fcarcelenc@unmsm.edu.pe. *Corresponding author.

${ }^{2}$ Departamento de Salud Animal y Salud Pública, Facultad de Medicina Veterinaria, Universidad Nacional Mayor de San Marcos, Lima, Perú. ${ }^{3}$ Estación Experimental El Mantaro, Instituto Veterinario de Investigación Tropical y de Altura, Universidad Nacional Mayor de San Marcos, Junín, Perú.

${ }^{4}$ Departamento de Procesos, Facultad de Química e Ingeniería Química, Universidad Nacional Mayor de San Marcos, Lima, Perú.
\end{abstract}

ABSTRACT: This study evaluated the effect of the three inulin levels (0.1\%, 0.2\%, 0.4\%) supplemented as a substitute for an antibiotic growth promoter (AGP, zinc bacitracin) and control in guinea pigs raised for human consumption. Fifty 14-day-old male guinea pigs were used. Productive parameters (weight gain, total dry matter intake, and feed conversion ratio (FCR)) and intestinal morphology of the duodenum, jejunum, and ileum at slaughter (70 days of age) were evaluated. An inverse relationship was observed between inulin levels and FCR (linear effect; $P=0.006)$. There was no statistically significant effect of the treatments on total dry matter intake and weight gain (P $>0.05)$. A linear effect of the inulin level on the villi's length (VL), villi's width $(V W)$, and length/depth ratio (VL/DC) in the duodenum; VW in the jejunum; and VL in the ileum $(P<0$.05) was reported. In conclusion, a linear effect of the increasing doses of inulin was found on the FCR and the morphological parameters of the duodenum's integrity, and no differences in the effects of the inulin added to the diet and the treatment with AGP were found.

Key words: inulin, productive parameters, intestinal morphology, guinea pigs.

Efeito da inclusão de diferentes níveis de inulina nos parâmetros produtivos e na morfologia intestinal em cobaias de engorda (Cavia porcellus)

RESUMO: $O$ objetivo do estudo foi avaliar o efeito da suplementação na dieta de cobaias com inulina, em níveis crescentes (0,1\%, $0,2 \%$, 0,4\%) como substituto para um antibiótico promotor de crescimento (AGP, bacitracina de zinco) além do grupo controle (dieta padrão). Foram utilizados 50 porquinhos-da-índia machos com 14 dias de idade. Os parâmetros produtivos foram avaliados do desmame aos 70 dias de idade e os parâmetros morfológicos intestinais foram avaliados no duodeno, jejuno e ileo no momento do abate. Foi encontrado um efeito linear do nível de inulina sobre na taxa de conversão alimentar (FCR; P=0,006), indicando que em niveis mais elevados de inulina o FCR diminui. Não houve diferença significativa entre os grupos quando avaliado o efeito dos diferentes tratamentos sobre o consumo de ração e ganho de peso corporal ( $P>0,05)$. Um efeito linear do nível de inulina foi encontrado no comprimento das vilosidades (VL), na largura das vilosidades (VW) e na relação comprimento / profundidade (VL/DC) no duodeno, sobre a VW no jejuno; e no VL no íleo $(P<0,05)$. Em conclusão, um efeito linear do aumento do nível de inulina foi encontrado na taxa de conversão alimentar e nos parâmetros morfológicos da integridade do duodeno, além disso, não houve diferença entre a adição de inulina na dieta e o tratamento com um antibiótico promotor de crescimento.

Palavras-chave: inulina, parâmetros produtivos, morfologia intestinal, cobaias.

\section{INTRODUCTION}

In the Andean Region, guinea pig meat has been eaten for thousands of years and is considered an important source of animal protein (AMPUERO, 2018). The use of antibiotics in livestock to maintain animal well-being, promote growth, and improve efficiency has been practiced for more than 50 years (ABD EL-HACK et al., 2020). AMPUERO (2018) reported the presence of antibiotics in muscle, liver, and kidney of guinea pig carcasses sold for human consumption in three cities of Peru. Therefore, we have been working on the search for alternatives (GUEVARA et al., 2016; PUENTE et al., 2019). 
Inulin is a natural carbohydrate used as an energy reserve and is found in more than 36,000 different plant species (SINGH \& SINGH, 2010). The most studied inulin property is its performance as a prebiotic (KOLIDA \& GIBSON, 2007). Prebiotics present a specific fermentation pathway that beneficially affects the health of the host, selectively stimulating the growth or activity of a limited number of beneficial bacteria and modifying the intestinal ecosystem (POURABEDIN \& ZHAO, 2015; DAVANI-DAVARI et al., 2019). It has been found to stimulate the growth of selective bacteria and reduce the growth of harmful bacteria (GIBSON et al., 2004; ZEAITER et al., 2019). The main products of the fermentation of prebiotics are short-chain fatty acids, which lower the $\mathrm{pH}$ of the intestine, promoting intestinal eubiosis (RÍOS-COVIÁN et al., 2016; NOCE et al., 2019).

Trials have been conducted to use oligosaccharides, such as inulin, to replace prophylactic antibiotics in rabbits, chickens, pigs, and guinea pigs (VERDONK et al., 2005; SAMANTA et al., 2013; GUEVARA et al., 2016). The morphological parameters of the intestinal epithelium, namely, villus length and width, crypt depth, and villus length/crypt depth ratio, have been used to determine the effect of prebiotics on productive parameters of livestock animals (CASTILLO et al., 2008). Most of the nutrient transport occurs in the small intestine; thus, the intestinal morphology parameters are evaluated microscopically in three sections. In addition, the three sections have different absorption capacities and histological morphologies (KIELA et al., 2016). REBOLÉ et al. (2010) detected positive correlation between villus length and crypt depth in chickens fed with a ration fortified with inulin (10 g/ $\mathrm{kg}$ ). It has been reported that crypt depth increases when severe diseases occur that causing the death of the intestinal epithelium. This increment compensates for the loss of cells from the intestinal villus (DUCATELLE et al., 2018). Similarly, GUEVARA et al. (2016) reported that inulin treatment improved the feed conversion ratio (FCR) and increased weight gain (WG) and carcass yield in guinea pigs. Considering the results of studies on the supplementation of inulin in livestock and the limited evidence of its use in guinea pigs, the objective of this study was to evaluate the effect of different levels of inulin as a substitute for antibiotic growth promoters on the production parameters and intestinal morphology of guinea pigs (Cavia porcellus).

\section{MATERIALS AND METHODS}

\section{Location}

This trial was carried out from October to December 2016 , in Jauja, Junin-Peru, at $11.83^{\circ} \mathrm{S}$ $75.40^{\circ} \mathrm{W}$ and $3320-\mathrm{m}$ altitude.

Animals

Fifty 14-day-old male guinea pigs, offspring from the maternal line (Prolific-dairy) belonging to the "Genial Breeding Guinea Pigs" (Cuyes G), with a weaning weight of $294 \pm 55 \mathrm{~g}$ were studied. This genetic line was obtained by genetic selection at the research center.

\section{Experimental design and treatments}

The study evaluated five treatments: dietary supplementation of three levels of inulin $(0.1 \%, 0.2 \%$, and $0.4 \%)$, dietary supplementation of a commercial AGP (0.3\% Zn-Bacitracin), and a control without supplements. For each treatment, ten experimental units were used. Each experimental unit corresponds to a randomly selected male weaned guinea pig from a unique litter. The subjects were evaluated from weaning to 70 days of age to determine the effect of the treatments on the productive parameters and intestinal morphology. Once the experimental units were weaned, they were placed in individual pens, 0.7 x $0.8 \times 0.5 \mathrm{~m}$ long, wide, and high, respectively, with a cement floor, wooden walls, and mesh, for treatment, and they continued receiving the previously assigned diet. The temperature and humidity, and light/dark cycle were according to natural conditions.

\section{Experimental diets}

The experimental diets consisted of a basal diet supplemented with AGP or inulin at different concentrations. The basal diet consisted of wheat bran and forage (a mixture of alfalfa, Italian ray-grass, and red clover). Inulin extracted from chicory (Cichorium intybus) and yacon (Smallanthus sonchifolius) was administered to wheat bran at three different concentrations: $1 \mathrm{~kg}$ of inulin per $1000 \mathrm{~kg}$ of wheat bran $(0.1 \%), 2 \mathrm{~kg}$ of inulin per $1000 \mathrm{~kg}$ of wheat bran $(0.2 \%)$, and $4 \mathrm{~kg}$ of inulin per $1000 \mathrm{~kg}$ of wheat bran $(0.4 \%)$. AGP treatment consisted of a commercial product with $10 \%$ zinc bacitracin. This product was administered at a concentration of $3 \mathrm{~kg}$ per $1000 \mathrm{~kg}$ of wheat bran. The forage was offered daily to the animals at a rate equivalent to $25 \%$ of their live weight. The wheat bran was offered twice a day at a rate equivalent to $5 \%$ of their live weight. Proximal analysis of the forage mixture, wheat bran, and basal diet is shown in table 1. The amounts of 
Table 1 - Proximal analysis of forage mixture, wheat bran, and basal diet.

\begin{tabular}{lccc}
\hline & Forage mixture & Wheat bran & Basal diet \\
\hline DE $(\mathrm{Kcal} / \mathrm{kg})^{*}$ & 3331.14 & 3638.36 & 3460.68 \\
TDN (\%) & 75.71 & 82.69 & 78.65 \\
CF $(\%)$ & 14.26 & 9.80 & 12.38 \\
NFE (\%) & 53.09 & 67.10 & 59.00 \\
CP (\%) & 21.33 & 15.10 & 18.70 \\
EE (\%) & 2.37 & 3.00 & 2.64 \\
Ash (\%) & 8.95 & 5.00 & 7.28 \\
DM (\%) & 24.06 & 87.70 & 50.89 \\
\hline
\end{tabular}

DE: digestible energy; TDN: total digestible nutrients; CF: crude fiber; NFE: nitrogen-free extract; CP: crude protein; EE: ether extract; DM: dry matter.

Basal diet: $25 \%$ of the live weight as forage and $5 \%$ of the live weight as treated wheat bran. The basal diet was formulated to cover a requirement of $2800 \mathrm{kcal}$ of $\mathrm{DE}, 10 \%$ of $\mathrm{CF}$, and $17 \%$ of $\mathrm{CP}$.

${ }^{*} \mathrm{DE}(\mathrm{Kcal})=4400 \times \mathrm{TDN}(\mathrm{kg})$.

${ }^{* *} \mathrm{TDN} \%=(0.50 \times \% \mathrm{CF})+(0.90 \times \% \mathrm{NFE})+(0.75 \times \% \mathrm{CP})+(2.25 \times 0.90 \times \% \mathrm{EE})$.

offered food and remaining food were recorded at the beginning of each day. Water was provided ad libitum.

\section{Study variables}

The productive parameters evaluated were: (i) weight gain (WG), obtained as the difference between the final weight and the initial weight of the animals, (ii) total dry matter intake (DMI), obtained as the difference between the weight of the dry matter of the offered food and the weight of the dry matter of the remaining food after a set period, and (iii) feed conversion ratio (FCR), obtained as the DMI/WG ratio.

The intestinal morphology parameters evaluated microscopically were: (i) length of the intestinal villi (VL), measured from villi apex to the entrance of the Lieberkühn crypt, (ii) width of the intestinal villi (VW), measured as a line perpendicular to the mid-section of the villus, (iii) depth of the Lieberkühn crypt (DC), measured from the entrance to the basal area of the crypt, and (iv) length/depth ratio (VL/DC).

The guinea pigs were slaughtered at 70 days old, following commercially used procedures to evaluate the intestinal morphology parameters (PUENTE et al., 2019). Three samples, each measuring $1 \mathrm{~cm}$ in length, were taken from the small intestine of each subject. Samples were taken from the duodenum ( $3 \mathrm{~cm}$ from the pylorus), jejunum (the middle section of the total measurement of the jejunal loops), and ileum ( $3 \mathrm{~cm}$ from the ileocecal junction). The segments were stained with hematoxylin-eosin and coded according to the individual animal and the appropriate treatment.

Seven to ten cross sections of each sample were microscopically examined, with each cross section containing between ten and twenty villi. Only intact villi and crypts were measured (ZHANG et al., 2005; VALLEJOS et al., 2015). For microscopic measurements, the light microscope LEICA DM500 was used, connected to a computer with SOFTWARE EZ (Leica Microsystems), which determines the distance between two points set by the observer. All reported measurements are expressed as mean.

\section{Statistical analysis}

A randomized complete block design, with the treatments as the mean effect and weaning weight as the random effect, was used to evaluate the effect of the treatments on the productive parameters (WG, DMI, and FCR). The animals were separated into two blocks based on average weight at weaning. The intestinal morphology (VL, VW, DC, and VL/DC) results were evaluated using a completely randomized design with five treatments. A Shapiro-Wilk test was conducted to check the normality assumption, and a Levene's test was performed to check the homoscedasticity assumption. Variables that did not follow normal distributions were transformed through the Box-Cox transformation. Then, ANOVA and Tukey tests were performed. Linear and quadratic polynomial contrasts were used to assess the effect of increasing levels of inulin (CONTROL, INUL 0.1\%, INUL $0.2 \%$, INUL $0.4 \%$ ), and comparative contrasts

Ciência Rural, v.51, n.11, 2021. 
were performed to compare the effects of AGP and inulin. Statistical calculations were performed with the help of SPSS version 25 and the Minitab18 package with a significance level of 0.05 .

\section{RESULTS AND DISCUSSION}

\section{Productive parameters}

The results obtained for the productive parameters are presented in table 2. An inverse relationship was observed between inulin level and FCR $(P=0.006)$. No other statistically significant relationships were recorded between the treatments and the productive parameters. Likewise, when comparing the effects of addition of inulin with AGP, no statistically significant differences were found $(\mathrm{P}>0.05)$.

These results showed that FCR decreased when inulin concentration increased, with the lowest FCR reported for the INUL $0.4 \%$ treatment. A low FCR implies higher efficiency of food use and; therefore, improvement in production. The benefit of this efficiency may be more noticeable when guinea pigs face stress such as pathogens or nutritional deficiencies. The productive parameter results coincide with previous reports. GUEVARA et al. (2016) observed a decreased FCR in guinea pigs that received $0.3 \%$ inulin. SAMOLIŃSKA et al. (2018) reported that inulin addition decreased FCR in hogs.

\section{Intestinal morphology}

In the duodenum, the VL, VW, and VL/ DC ratio were statistically higher in the INUL $0.4 \%$ group than in the control group (Table 3). Likewise, the VW and VL/DC ratio were significantly higher in the AGP group than in the control group. In addition, a significant linear response was found between inulin level and $\mathrm{VL}, \mathrm{VW}$, and $\mathrm{VL} / \mathrm{DC}$ ratio
$(\mathrm{P}<0.05)$. No statistically significant difference was reported between the AGP and inulin groups in the duodenum's morphological variables except VW, which was higher in inulin groups $(\mathrm{P}=0.041)$. These findings suggested that inulin has a comparable effect to that of AGP and could serve as a substitute.

It is indicated that the treatments used had a significant effect on the intestinal morphology parameters at the duodenum section, concluding that higher levels of inulin improved the intestinal morphology parameters in the treated guinea pigs and that the INUL $0.4 \%$ treatment had the best effect on intestinal morphology. An increase in the VL and WV of the duodenum is related to a greater absorption surface area and could lead to a better absorption of nutrients (AWAD et al., 2011). Increasing of the VL/ DC ratio is directly related to the increased renewal of epithelial cells (CHICHLOWSKI et al., 2007).

HigherVLand WV values indicateincreases in intestinal absorption surface area, enzyme activity, and nutrient transport activity (PLUSKE et al., 1996). Higher DC values, conversely, often indicate villus damage requiring increased cell renewal (PUENTE et al., 2019). Likewise, cell turnover increases the rate of renewal to achieve villus regeneration, which has been related to a greater DC (YASON et al., 1987). High cell renewal requires consumption of energy and protein for the maintenance of the intestine, to the detriment of the productive efficiency of the animal (XU et al., 2003). An imbalance between production and cell death causes a decrease in the VL/DC ratio (PUENTE et al., 2019). Villus shortening and crypt deepening have been associated with inflammation and toxins (YASON et al., 1987).

In the jejunum, inulin level had a positive correlation with VW $(\mathrm{P}=0.013)$. No differences in other intestinal morphology parameters were observed

Table 2 - Effects of treatments on weight gain (WG), dry matter intake (DMI), and feed conversion ratio (FCR) in fattening guinea pigs (Cavia porcellus) $)^{*}$

\begin{tabular}{|c|c|c|c|c|c|c|c|c|c|c|c|c|}
\hline \multirow[t]{2}{*}{ Variables } & \multicolumn{5}{|c|}{---------------------TREATMENT------------------- } & \multirow[t]{2}{*}{ Pooled SEM ${ }^{\ddagger}$} & \multicolumn{5}{|c|}{--------Contrast (p-value) } & \multirow[t]{2}{*}{ ANOVA (p-value) } \\
\hline & $\operatorname{Con}^{\dagger}$ & $\begin{array}{l}\text { INUL } \\
0.1 \%{ }^{\S}\end{array}$ & $\begin{array}{l}\text { INUL } \\
0.2 \% \text { s }\end{array}$ & $\begin{array}{l}\text { INUL } \\
0.4 \%^{+}\end{array}$ & $\mathrm{AGP}^{\diamond}$ & & $\mathrm{C} 1$ & $\mathrm{C} 2$ & C3 & C4 & C5 & \\
\hline WG $(\mathrm{g})$ & 594.9 & 615.1 & 593.5 & 627.8 & 603.0 & 9.45 & n.s. & n.s. & n.s. & n.s. & n.s. & n.s. \\
\hline DMI (g) & 2842.3 & 3012.7 & 2767.3 & 2737.5 & 2773.3 & 44.89 & n.s. & n.s. & n.s. & n.s. & n.s. & n.s. \\
\hline FCR & 5.09 & 4.94 & 4.70 & 4.37 & 4.63 & 0.08 & $<0.01$ & n.s. & n.s. & n.s. & n.s. & n.s. \\
\hline
\end{tabular}

"Data represent means of ten experimental units per treatment; ${ }^{\dagger}$ Con: control; ${ }^{\S}$ INUL $0.1 \%$ : inulin $0.1 \%$; ${ }^{\$}$ INUL $0.2 \%$ : inulin $0.2 \%$; ${ }^{+}$INUL $0.4 \%$ : inulin $0.4 \%$; ${ }^{\circ} \mathrm{AGP}$ : antibiotic growth promoter; ${ }^{\ddagger} \mathrm{SEM}$ : standard error of mean; ${ }^{\circ} \mathrm{C} 1$ : linear; $\mathrm{C} 2$ : quadratic; $\mathrm{C} 3$ : inulin vs. AGP; $\mathrm{C} 4$ : control vs. inulin; C5: control vs. AGP; ${ }^{n}$ n.s.: non-significant. 
Table 3 - Effects of the inclusion of different levels of inulin and of the addition of zinc bacitracin on intestinal morphology parameters of the duodenum, jejunum, and ileum in guinea pigs (Cavia porcellus).

\begin{tabular}{|c|c|c|c|c|c|c|c|c|c|c|c|c|}
\hline \multirow[t]{2}{*}{ Variables } & \multicolumn{5}{|c|}{------------------TREATMENT------------------ } & \multirow[t]{2}{*}{ Pooled SEM } & \multicolumn{5}{|c|}{ 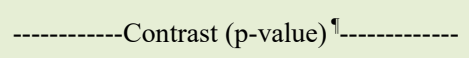 } & \multirow[t]{2}{*}{$\begin{array}{l}\text { ANOVA } \\
\text { (p-value) }\end{array}$} \\
\hline & $\operatorname{Con}^{\dagger}$ & $\begin{array}{l}\text { INUL } \\
0.1 \%\end{array}$ & $\begin{array}{l}\text { INUL } \\
0.2 \%{ }^{\$}\end{array}$ & $\begin{array}{l}\text { INUL } \\
0.4 \% \%^{+}\end{array}$ & $\mathrm{AGP}^{\diamond}$ & & $\mathrm{C} 1$ & $\mathrm{C} 2$ & $\mathrm{C} 3$ & $\mathrm{C} 4$ & $\mathrm{C} 5$ & \\
\hline \multicolumn{13}{|c|}{ 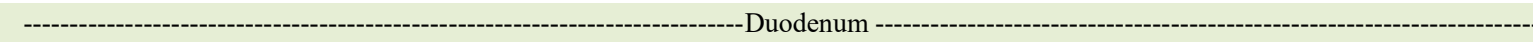 } \\
\hline $\mathrm{VL}(\mu \mathrm{m})$ & $726.7^{\mathrm{b}}$ & $749.7^{\mathrm{a}, \mathrm{b}}$ & $830.9^{\mathrm{a}, \mathrm{b}}$ & $858.5^{\mathrm{a}}$ & $835.9^{\mathrm{a}, \mathrm{b}}$ & 12.39 & $<0.001$ & n.s. & n.s. & $<0.01$ & $<0.01$ & $<0.01$ \\
\hline $\mathrm{VW}(\mu \mathrm{m})$ & $105.0^{\mathrm{b}}$ & $99.8^{\mathrm{b}}$ & $119.6^{\mathrm{a}}$ & $132.8^{\mathrm{a}}$ & $125.9^{\mathrm{a}}$ & 1.58 & $<0.001$ & n.s. & $<0.05$ & $<0.01$ & $<0.001$ & $<0.001$ \\
\hline $\mathrm{DC}(\mu \mathrm{m})$ & 337.1 & 333.4 & 347.7 & 288.0 & 296.3 & 8.32 & n.s. & n.s. & n.s. & n.s. & n.s. & n.s. \\
\hline VL/DC & $2.3^{\mathrm{c}}$ & $2.3^{\mathrm{c}}$ & $2.4^{\mathrm{b}, \mathrm{c}}$ & $3.1^{\mathrm{a}}$ & $2.9^{\mathrm{a}, \mathrm{b}}$ & 0.07 & $<0.001$ & n.s. & n.s. & n.s. & $<0.01$ & $<0.001$ \\
\hline \multicolumn{13}{|c|}{ 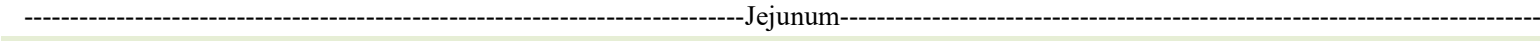 } \\
\hline $\mathrm{VL}(\mu \mathrm{m})$ & 431.1 & 449.2 & 456.2 & 487.7 & 454.0 & 11.09 & n.s. & n.s. & n.s. & n.s. & n.s. & n.s. \\
\hline $\mathrm{VW}(\mu \mathrm{m})$ & 113.4 & 125.2 & 135.4 & 138.8 & 126.1 & 4.60 & $<0.05$ & n.s. & n.s. & $<0.05$ & n.s. & n.s. \\
\hline $\mathrm{DC}(\mu \mathrm{m})$ & 220.6 & 231.1 & 249.1 & 238.8 & 236.5 & 5.51 & n.s. & n.s. & n.s. & n.s. & n.s. & n.s. \\
\hline VL/DC & 2.0 & 2.0 & 1.9 & 2.0 & 2.0 & 0.05 & n.s. & n.s. & n.s. & n.s. & n.s. & n.s. \\
\hline \multicolumn{13}{|c|}{ 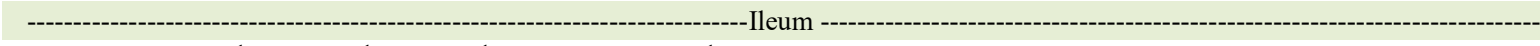 } \\
\hline $\mathrm{VL}(\mu \mathrm{m})$ & $245.2^{\mathrm{b}}$ & $254.2^{\mathrm{a}, \mathrm{b}}$ & $281.0^{\mathrm{a}, \mathrm{b}}$ & $286.5^{\mathrm{a}}$ & $278.4^{\mathrm{a}, \mathrm{b}}$ & 5.20 & $<0.05$ & n.s. & n.s. & $<0.05$ & $<0.05$ & $<0.05$ \\
\hline $\mathrm{VW}(\mu \mathrm{m})$ & $126.3^{\mathrm{a}, \mathrm{b}}$ & $126.1^{\mathrm{a}, \mathrm{b}}$ & $129.6^{\mathrm{a}, \mathrm{b}}$ & $121.6^{\mathrm{b}}$ & $136.7^{\mathrm{a}}$ & 4.88 & n.s. & n.s. & $<0.001$ & n.s. & $<0.01$ & $<0.05$ \\
\hline $\mathrm{DC}(\mu \mathrm{m})$ & 180.2 & 176.0 & 187.9 & 198.2 & 191.3 & 5.01 & n.s. & n.s. & n.s. & n.s. & n.s. & n.s. \\
\hline VL/DC & 1.4 & 1.5 & 1.5 & 1.5 & 1.5 & 0.05 & n.s. & n.s. & n.s. & n.s. & n.s. & n.s. \\
\hline
\end{tabular}

${ }^{*}$ Data represent means of ten experimental units per treatment; ${ }^{\dagger} \mathrm{Con}$ : control; ${ }^{\S} \mathrm{INUL} 0.1 \%$ : inulin $0.1 \%$; ${ }^{\$} \mathrm{INUL} 0.2 \%$ : inulin $0.2 \%$; ${ }^{+} \mathrm{INUL}$ $0.4 \%$ : inulin $0.4 \%$; ${ }^{\diamond} \mathrm{AGP}$ : antibiotic growth promoter; ${ }^{\ddagger} \mathrm{SEM}$ : standard error of mean; ${ }^{\uparrow} \mathrm{C} 1$ : linear; C2: quadratic; C3: inulin vs. AGP; C4: control vs. inulin; C5: control vs. AGP; VL: length of the intestinal villi; VW: width of the intestinal villi; DC: depth of the Lieberkühn crypt; VL/DC: length/depth ratio; ${ }^{\#}$ n.s.: non-significant. Different letters $(\mathrm{a}, \mathrm{b}, \mathrm{c})$ indicate significant differences between treatments $(\mathrm{P}<$ $0.05)$.

between the treatment groups (Table 3 ). In the ileum, INUL $0.4 \%$ treatment resulted in significantly higher VL levels than did the control treatment $(\mathrm{P}<0.05)$ (Table 3). Regarding the VW variable, the INUL 0.4\% treatment had a lower VW than the AGP treatment (P $<0.05)$. A significant linear effect was reported when increasing the inulin concentrations on the VL $(\mathrm{P}=$ $0.026)$, indicating that inulin may serve to lengthen intestinal villi. In general, it can be highlighted that in none of the intestinal sections, a difference was found between AGP treatment and the addition of prebiotics $(\mathrm{P}>0.05)$, except for $\mathrm{VW}$, where a greater VW was found with the AGP treatment $(\mathrm{P}=0.001)$. Across all sections, results of AGP and inulin trials were comparable, indicating that inulin has the same effect on intestinal morphology as AGP.

This study found a significant effect of inulin on the intestinal morphology of the duodenum. The results of inulin on the jejunum and ileum were inconclusive. The improvement in morphology parameters may be more noticeable when guinea pigs face stressful conditions such as pathogens and nutritional deficiencies and others (PUENTE et al., 2019). There were no significant changes in the DC in any of the intestinal sections; this may be due to the lack of tissue replacement and epithelial regeneration, as the study was conducted under ideal conditions (PAULUS et al., 1992; DUCATELLE et al., 2018).

The present investigation showed that inulin supplementation significantly improves the intestinal morphology of the guinea pig duodenum. This could be because short-chain fatty acids increase the development of villi because of its effect on the luminal environment and direct action on intestinal epithelium, favoring intestinal morphology and stimulating the proliferation of cells (GÁLFI \& BOKORI, 1990). An improvement in intestinal morphology was reported in guinea pigs fed with diet supplemented with butyric acid in the form of sodium butyrate (VALLEJOS et al., 2015). The increase in $\mathrm{VL}$ produces an improvement in the absorption and digestion capacity of the intestine due to the increased expression of brush border enzymes and nutrient transport systems and increased absorptive surface area (PLUSKE et al. 1996).

The results of this study coincided with a report by REBOLÉ et al. (2010), which detected an increase in the VL/DC ratio and DC in chickens fed a diet supplemented with inulin $(10 \mathrm{~g} / \mathrm{kg})$. This may occur because inulin lowers the $\mathrm{pH}$ of the intestine, 
promoting intestinal eubiosis (decrease in pathogenic flora and increase in beneficial flora) (NOCE et al., 2019), leading to a favorable environment for beneficial bacteria. Inulin has been observed to selectively stimulate the growth of specific bacteria in the colon (Bifidobacteria and Lactobacilli) and reduce the growth of harmful bacteria ( $E$. coli and bacteria of the genus Clostridium) (ZEAITER et al., 2019).

\section{CONCLUSION}

Inulin had a linear effect on feed conversion ratio and morphology parameters of the duodenum in livestock guinea pigs (Cavia porcellus).

No differences were reported between the effects of inulin and the commercial antibiotic growth promoter on the productive parameters and intestinal morphology of the study subjects.

\section{ACKNOWLEDGEMENTS}

The authors thank the Universidad Nacional Mayor de San Marcos for financial support for this research work and the "El Mantaro Experimental Station" for its contribution to the research project by allowing the use of research facilities.

\section{BIOETHICS AND \\ BIOSECURITY COMMITTEE APPROVAL}

We, the authors of the article entitled "Effect of the inclusion of different levels of inulin on the productive parameters and the intestinal morphology in fattening guinea pigs (Cavia porcellus)," declare, for all due purposes, that the project that reports the present data has not been submitted for evaluation to the Ethics Committee of the "Facultad de Medicina Veterinaria of the Universidad Nacional Mayor de San Marcos." However, the reviewers of the Vice-Rectorate of Research of the Universidad Nacional Mayor de San Marcos have approved the methodology of the research project. We are aware of the content of the Brazilian resolutions of the National Council for Control of Animal Experimental - CONCEA "http://www.mct.gov. br/index.php/content/view/310553.html" if a study involves animal subjects, and sampling procedures were carried out as per animal welfare protocols.

Thus, we assume full responsibility for the presented data and are available for answering possible questions, should they be required to by the competent authorities.

\section{DECLARATION OF CONFLICT OF INTEREST}

The authors declare that they have no personal, academic, political, or economic conflicts of interest related to the publication.

\section{AUTHORS' CONTRIBUTIONS}

All authors contributed equally to the conception and writing of the manuscript. All authors critically revised the manuscript and approved the final version.

\section{REFERENCES}

ABD EL-HACK, M. E. et al. Probiotics in poultry feed: A comprehensive review. Journal of Animal Physiology and Animal Nutrition. v.104, n.6, p.1835-1850. 2020. Available from: $<$ https://doi.org/10.1111/jpn.13454>. Accessed: Sept. 30, 2020. doi: $10.1111 /$ jpn. 13454 .

AMPUERO, J. Determinación de residuos y antibióticos en músculo, hígado y riñón de cuy de crianza intensiva en cuatro ciudades del país. M.V. thesis, Univ. Científica del Sur, Lima, Perú. 2018. Available from: <https://repositorio.cientifica.edu.pe/ handle/20.500.12805/552>. Accessed: Jul. 25, 2020.

AWAD, W. et al. Evaluation of the chicory inulin efficacy on ameliorating the intestinal morphology and modulating the intestinal electrophysiological properties in broiler chickens. Journal of Animal Physiology and Animal Nutrition, v.95, n.1, p.65-72. 2011. Available from: <http://dx.doi.org/10.1111 /j.1439-0396.2010.00999.x>. Accessed: Jul. 25, 2020. doi:10.1111/ j.1439-0396.2010.00999.x.

CASTILLO, M. et al. Use of mannanoligosaccharides and zinc chelate as growth promoters and diarrhea preventative in weaning pigs: effects on microbiota and gut function. Journal of Animal Science. v.86, n.1, p.94-101, 2008. Available from: $<$ http://dx.doi. org/10.2527/jas.2005-686>. Accessed: Jul. 25, 2020. doi: 10.2527/ jas.2005-686.

CHICHLOWSKI, M. et al. Microarchitecture and spatial relationship between bacteria and ileal, cecal and colonic epithelium in chicks fed a direct- fed microbial, PrimaLac, and Salinomycin. Poultry Science. v.86. p.1121-1132. 2007. Available from: <https://doi.org/10.1093/ps/86.6.1121>. Accessed: Jul. 25, 2020. doi: $10.1093 / \mathrm{ps} / 86.6 .1121$

DAVANI-DAVARI, D. et al. Prebiotics: Definition, types, sources, mechanisms, and clinical applications. Foods. v.8, n.92, p.1-27. 2019. Available from: <https://www.mdpi.com/23048158/8/3/92>. Accessed: Jul. 25, 2020 doi:10.3390/foods8030092.

DUCATELLE, R. et al. Biomarkers for monitoring intestinal health in poultry: present status and future perspectives. Veterinary research, v.49, n.1, p.1-9, 2018 Available from; <https://dx.doi. org/10.1186/s13567-018-0538-6>. Accessed: Jul. 25, 2020. doi: $10.1186 / \mathrm{s} 13567-018-0538-6$.

GÁLFI, P.; BOKORI, J. Feeding trial in pigs with a diet containing sodium n-butyrate. Acta Veterinaria Hungarica v.38, n.1-2, p.3-17. 1990 Available from: <https://www.researchgate.net/ publication/21054969_Feeding_trial_in_pigs_with_a_diet_ containing_sodium_n-butyrate>. Accessed: Jul. 26, 2020.

GIBSON, G. et al. Dietary modulation of the human colonic microbiota: updating the concept of prebiotics. Nutrition Research Reviews. v.17, n.2, p.259-275. 2004. Available from: $<$ http://dx.doi.org/10.1079/NRR200479>. Accessed: Jul. 26, 2020. doi: $10.1079 /$ NRR200479.

GUEVARA, J. et al. Efecto de la inulina como prebiótico natural sobre los parámetros productivos de cuyes en crecimiento. Revista Peruana de Química e Ingeniería Química, v.19, n.2, p.61-68. 2016. Available from: <https://revistasinvestigacion. unmsm.edu.pe/index.php/quim/article/view/13094/11619>. Accessed: Jul. 26, 2020. 
KIELA, P. R.; GHISHAN, F.K. Physiology of intestinal absorption and secretion. Best Practice \& Research Clinical Gastroenterology; v.30, n.2, p.145-159. 2016. Available from: $<$ https://doi.org/10.1016/j.bpg.2016.02.007>. Accessed: Jul. 25, 2020. doi: 10.1016/j.bpg.2016.02.007.

KOLIDA, S.; GIBSON, G.R. Prebiotic capacity of inulin-type fructans. Journal of Nutrition. v.137, n.11, p.2503S-2506S. 2007. Available from: <https://pdfs.semanticscholar.org/12e8/ ebba3022b10dcc251eff6c70f6b9958cb526.pdf >. Accessed: Jul. 26, 2020.

NOCE, A. et al. Impact of gut microbiota composition on onset and progression of chronic non-communicable diseases. Nutrients. v.11, n.5, p.1073. 2019. Available from: <http://dx.doi.org/10.3390/ nu11051073>. Accessed: Jul. 26, 2020. doi: 10.3390/nu11051073.

PAULUS, U. et al. A model of the control of cellular regeneration in the intestinal crypt after perturbation based solely on local stem cell regulation. Cell proliferation. v.25, n.6, p.559-578. nov. 1992. Available from: $<$ http://dx.doi.org/10.1111/j.1365-2184.1992. tb01460.x>. Accessed: Jul. 26, 2020. doi: 10.1111/j.13652184.1992.tb01460.x.

PLUSKE, J. et al. Maintenance of villus height and crypt depth, and enhancement of disaccharide digestion and monosaccharide absorption, in piglets fed on cows' whole milk after weaning. British Journal of Nutrition, v.76, n.3, p.409-422, 1996.

POURABEDIN, M.; ZHAO, X. Prebiotics and gut microbiota in chickens. FEMS Microbiology Letters. v. 362, n.15, p.1-8 2015. Available from: <http://dx.doi.org/10.1093/femsle/fnv122>. Accessed: Jul. 26, 2020. doi: 10.1093/femsle/fnv122.

PUENTE, J. et al. Efecto de la suplementación con niveles crecientes de probióticos sobre la histomorfometría del intestino delgado del cuy (Cavia porcellus). Revista de Investigaciones Veterinarias del Perú, v.30, n.2, p.624-633. 2019. Available from: $<$ https://dx.doi.org/10.15381/rivep.v30i2.16086>. Accessed: Jul. 25, 2020. doi: 10.15381/rivep.v30i2.16086

REBOLÉ A. et al. Effects of inulin and enzyme complex, individually or in combination, on growth performance, intestinal microflora, cecal fermentation characteristics, and jejunal histomorphology in broiler chickens fed a wheat-and barleybassed diet. Journal Poultry Science, v.89, n.2, p.276-286. 2010. Available from: <http://dx.doi.org/10.3382/ps.2009-00336>. Accessed: Jul. 26, 2020. doi: 10.3382/ps.2009-00336.

RÍOS-COVIÁN, D. et al. Intestinal short chain fatty acids and their link with diet and human health. Frontiers in Microbiology. v.7, n.185, 2016. Available from: <http://dx.doi.org/10.3389/ fmicb.2016.00185>. Accessed: Jul. 26, 2020. doi: 10.3389/ fmicb.2016.00185.

SAMANTA A. K. et al. Prebiotic inulin: Useful dietary adjuncts to manipulate the livestock gut microflora. Brazilian Journal of
Microbiology. v.44, n.1, p.1-14. 2013. Available from: <http:// dx.doi.org/10.1590/S1517-83822013005000023>. Accessed: Jul. 26, 2020. doi: 10.1590/S1517-83822013005000023.

SAMOLIŃSKA, W. et al. Comparative effect of different dietary inulin sources and probiotics on growth performance and blood characteristics in growing-finishing pigs. Archives of Animal Nutrition, v.72, n.5, p.379-395. 2018. Available from: <http:// dx.doi.org/10.1080/1745039X.2018.1505147>. Accessed: Jul. 25, 2020. doi: 10.1080/1745039X.2018.1505147.

SINGH, R. S.; SINGH R.P. Production of fructooligosaccharides from inulin by endoinulinases and their prebiotic potential. Food Technology Biotechnology. v.48, n.4, p.435-450. 2010. Available from: $\quad<$ https://www.researchgate.net/publication/257939767 Production_of_Fructooligosaccharides_from_Inulin_by Endoinulinases_and_Their_Prebiotic_Potential>. Accessed: Jul. 26,2020 .

VALLEJOS, P.et al. Efecto de la suplementación de butirato de sodio en la dieta de cuyes (Cavia porcellus) de engorde sobre el desarrollo de las vellosidades intestinales y criptas de lieberkühn. Revista de Investigaciones Veterinarias del Perú. v.26, n.3, p.395-403. set. 2015. Available from: $<$ http://dx.doi.org/10.15381/ rivep.v26i3.11186>. Accessed: Jul. 26, 2020. doi: 10.15381/rivep. v26i3.11186.

VERDONK, J. M. et al. Application of inulin-type fructans in animal feed and pet food. British Journal of Nutrition. v.93, n.S1, p.S125-S138. 2005. Available from: <http://dx.doi.org/10.1079/ BJN20041355>. Accessed: Jul. 26, 2020. doi: 10.1079/ BJN20041355.

YASON, C. V. et al. Pathogenesis of rotavirus infection in various age groups of chickens and turkeys: Pathology. American journal of veterinary research. v.48, n.6, p.927-938. 1987.

$\mathrm{XU}, \mathrm{Z}$. et al. Effects of dietary fructooligosaccharide on digestive enzyme activities, intestinal microflora and morphology of male broilers. Poultry Science. v.82. p.1030-1036. 2003. Available from: $<$ https://doi.org/10.1093/ps/82.6.1030>. Accessed: Jul. 26 , 2020. doi: $10.1093 / \mathrm{ps} / 82.6 .1030$.

ZEAITER, Z. et al. Extraction and characterization of inulin-type fructans from artichoke wastes and their effect on the growth of intestinal bacteria associated with health. Bio Med Research International. v.2019, Article ID 1083952, p.1-8. 2019. Available from: <http://dx.doi.org/10.1155/2019/1083952>. Accessed: Jul. 26, 2020. doi: 10.1155/2019/1083952.

ZHANG, A. et al. Effects of yeast (Saccharomyces cerevisiae) cell components on growth performance, meat quality, and ileal mucosa development of broiler chicks. Poultry Science. v.84, n.7, p.1015-1021. 2005. Available from: $<$ http://dx.doi. org/10.1093/ps/84.7.1015>. Accessed: Jul. 26, 2020. doi: $10.1093 / \mathrm{ps} / 84.7 .1015$. 